Published January 2020

ENGLISH TEACHING AND LINGUISTICS

JOURNAL (ETLiJ)

ISSN 2716-0831 (online) | http://jurnal.umsu.ac.id/index.php/ETLiJ/index

\title{
The Correlation Between Adjective Mastery And Students' Writing Descriptive Text At SMA Swasta Persiapan Stabat
}

\author{
Efrini Panjaitan, S.Pd.I, M.Hum \\ Elga, S.Pd \\ STKIP Budidaya Binjai \\ e-mail: efrinipanjaitan@gmail.com
}

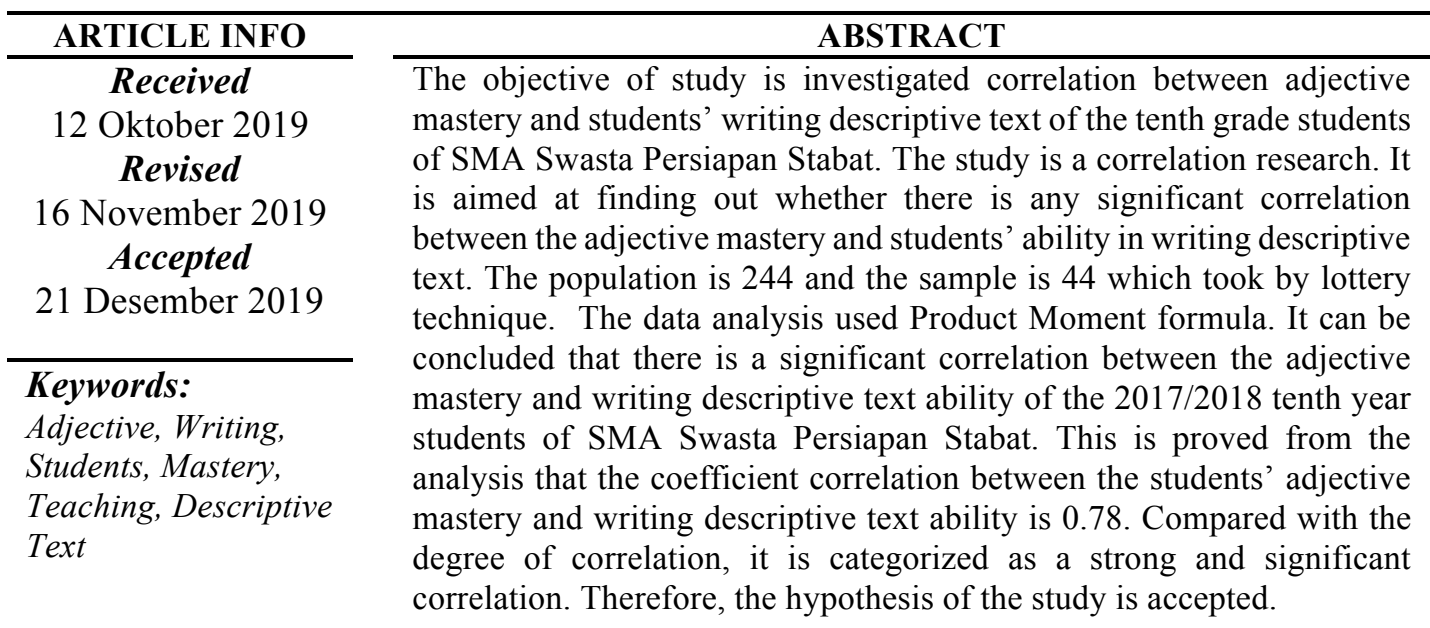

Cara Sitasi:

Panjaitan, E \& Elga. (2019). The Correlation Between Adjective Mastery And Students' Writing Descriptive Text At SMA Swasta Persiapan Stabat. English Teaching and Linguistics Journal, Vol. 1, No., 1, pp16-27

\section{INTRODUCTION}

Writing is a very important capability for being owned by students. Through writing, each person will be able to convey feelings, ideas, and announcements to others. It allows students to express something about themselves, explore and explain ideas. Student can convey their ideas in their mind by organizing them into a good text so that the others know them and they can think critically. "As one of the four language skills, writing has always formed part of the syllabus in the teaching of English." "This indicates that 
writing plays an important role in language teaching. Through writing the students can communicate in English in writing form. They can communicate to their readers through writing.

Not everyone can be a good writer, even in their own language. Writing in foreign language like English can be more difficult. There are many differences between the Indonesian language writing and the English writing, such as differences in using appropriate grammatical, and vocabularies. With these differences, the learning writing in English can be a frustrating task for students. Consequently, the learning objective is still difficult to achieve. Therefore, the writing instruction in the classroom should provide students with a series of planned learning experiences to help them understand the nature of writing process.

When the writer gave writing test, it found that the students of SMA Swasta Persiapan Stabat still had little understanding about adjectives. When they were asked to use adjective, the students always forgot and needed to look at the dictionary to find out the adjective used for describing something. They also thought that adjective were similar with verbs. For example, when the writer asked them to write the translation of this sentence "Ibu saya sakit kemarin," they wrote "My mother sick yesterday," instead of "My mother was sick yesterday."

Descriptive text is among the texts that students should learn and understand. This text is specifically used to describe person, animal, or other things by clarifying their physical characteristics. In giving descriptions, a writer or speakers commonly uses adjectives because adjectives are usually used to give explanation about the condition of nouns such as people, animals or things. Students should be familiar with descriptive text and adjectives. In other words, since adjective are used in describing nouns, so adjectives and descriptive text are two things which are closely correlated.

The students also got problem in writing descriptive text. This could be seen from the result knowing from pra research that has been done at SMA Persiapan Stabat. For most students, writing is a difficult task to do because the students should think and create many words to arrange into sentences and then develop them into a text. The students were confused to write their ideas since their vocabularies were less. Adjectives as one of the language features of descriptive texts were confusing for them. These factors affected the students' ability in their writing.

Based on the problem above, the writer would like to conduct a study relating to adjectives and writing descriptive text. The title of this study is "The Correlation between Adjective Mastery and Students' Writing Descriptive Text of Tenth Grade Students of SMA Swasta Persiapan Stabat 2017/2018."

\section{ADJECTIVE}

"The word 'adjective' is from Latin ad jacere meaning 'throw to' or 'add'. In the grammatical sense, this means to add the characteristics of something, i.e. to qualify it". "Another definition is that adjectives describe nouns and pronouns. They give more information about people, places, and things" 3 . This indicates that nouns and pronouns are words which are very common to describe by using adjectives. By using adjective, nouns and pronouns become more clearly.

In addition, "an adjective is a word used to restrict the application of a noun or pronoun by adding something to its meaning" " This definition indicates that 
adjective clarifies and describes the characteristics of a noun or pronoun by giving additional information. In the following examples, the highlighted words are adjectives: a) she wore a beautiful dress; b) he writes meaningless letters.

\section{KINDS OF ADJECTIVES}

There are several types of adjective in English grammar. Those are:

a. Proper Adjective

Proper adjective is a word that modifies nouns and pronouns and is formed from a proper noun. A proper noun is the specific name used for any person, place, or thing.

Examples:

a. I was born in Italy

b. He visited the Washington Monument.

b. Descriptive Adjective

"Descriptive adjectives name a quality or condition of the element modified"5. The descriptive adjectives are used to express the size, color, or shape of a person, a thing, an animal, or a place. They are used to provide more information to a noun by describing or modifying it. For example:

a. She brushed her long brown hair.

b. The slender man appeared out of nowhere.

c. Quantitative Adjective

Quantitative adjectives are called adjective of quality show how much of a thing is meant. They restrict the application of a noun to such things as are of the quantity or degree denotes by the adjectives.

Examples:

a. He lost all his wealth.

b. She ate the whole apple.

Adjectives of quantity are also called adjectives of degree and are always followed by a singular noun and this noun must always be either a noun material or an abstract noun.

d. Numeral Adjective

Numeral adjectives are called adjective of number. They show how many persons or thing are meant, or in what order a person or thing stands.

e. Demonstrative Adjective

Demonstrative adjectives point out which person or thing is meant, they restrict the application of a noun those person or thing that are to be pointed out by the adjective.

a. These mangoes are sour

a. Don't be in such a hurry

b. I hate such thing

f. Interrogative Adjectives

Interrogative adjective restrict the application of a noun by asking question.

Examples:

a. What cake are you eating? 
b. Which car is yours?

g. Distributive Adjectives

Distributive adjectives are normally used with singular nouns. They include "each", "every", "either", and "neither" and are used to refer to members of a group as individuals.

Examples:

a. Each participant was asked to complete a survey.

b. Each of the participants received compensation.

h. Possessive Adjectives

Possessive adjectives are used before nouns, and quality them like adjectives.

My, Its, Your, Her, Their, Our, His

Examples:

a. My father is a teacher

b. Is your father also a teacher

\section{WRITING}

"Writing is a method of representing language in visual or tactile form"6. Writing systems use sets of symbols to represent the sounds of speech, and may also have symbols for such things as punctuation and numerals. In addition, "writing is organizing and packaging information and knowledge for readers"? Through writing, we can inform others, carry out transaction, persuade, infuriate, and tell what we feel. The readers will obtain more information and knowledge from the product of writing they read.

Brown explained that "writing is the representation of spoken language, written language is almost same with spoken language, and the difference is the performance of written language is conveyed in graphical"8. Besides Brown also mentioned that written products are the result of thinking, drafting, and revising procedures, specialized skills is required in written language, and that not every speaker develops naturally.

"To make a good writing, a writer should consider three characteristics of good writing, namely coherence, cohesion, and unity"9.

a. Coherence

A paragraph has coherence when the supporting sentences are ordered according to a principle. The sentences are put in order so that the reader can understand your ideas easily. The principles for ordering depend on the types of paragraph you are writing. Coherence means stick together, coherence is basically a matter of having the part of a piece of writing in the right with the clear process.

b. Cohesion

Another characteristic of a good paragraph is cohesion. When a paragraph has cohesion, all the supporting sentences connect to each other in their support of the topic sentence. 


\section{c. Unity}

The final characteristic of a well-written paragraph is unity. All the supporting sentences should relate to the topic sentence. Order in text or paragraph is like organization easy, but is smaller in space so it may be simpler to consider order as direction. Thus order chronological steps to express the idea the written form. Richards and Renandya state that "the process of teaching writing consists of four basic stages namely planning, drafting, revising, and editing".

\section{DESCRIPTIVE TEXT}

"Descriptive is a type of text function to describe particular person, place, or thing. The students can use simple present and adjective clause in writing descriptive text". The aim of descriptive text is basically to give information. It focuses on specific participants. The description includes parts, qualities and characteristics. "A descriptive text is basically aimed at giving information to the readers about characteristic features of a thing, person, or animal". The social context of this text is to describe a specific thing, animal, or human being (certain thing, our pets or someone we know well), it is different from report text which describes something in general (for example a specific of animal species, an architect of certain era, and so on).

As Pharr stated, descriptive comes in two basic forms: objective and subjective. Objective description is used in the science, in business, and in technology; in this approach, the writers describe their subject without including their personal responses. "Subjective description allows the writer to show personal connection to his or her subject"10. Descriptive text can be different based on the writer's opinion. It can be happened in subjective description, for example descriptive text about the writer's mother. Meanwhile in objective description, the writer cannot put their personal opinion in descriptive text.

Description helps the reader, through his or her imagination, to visualize a scene or a person, or to understand a sensation or an emotion. "Description adds an important dimension to our lives because it moves our emotion and expands our experience." 11 Description expands our experience by taking us to place we might not otherwise know much about, which explains the popularity of descriptive travel essay in magazines and newspapers

A typical description has an opening paragraph introducing the subject of the description, followed by a series of paragraphs each describing one feature of the subject. There can also be a final concluding section that signals the end of the description. It can conclude that descriptive consist of two general structures which are introduction to introduce the object and description to explain the features of the object one by one and the last is make a summary about the object.

\section{THE WAY OF TEACHING ADJECTIVE}

Most of the teaching of grammar is done in a traditional manner, where the teacher does the talking and the students are passive audience. One does not know 
how much of the knowledge is absorbed by the students. To make Students motivated and engaged in the process of learning and this makes them learn better. "The following are some suggested activities to make the teaching/learning of adjectives more enjoyable and effective". These activities have been inspired by ideas of several practicing teachers.

\section{Show and tell}

The teachers ask the students to bring different things that they have collected. Each student comes and displays his object. The others are asked to describe it. The teacher keeps collating the answers. The different adjectives that the students come up with can be displayed in the class later. For example, a pencil box can be yellow, long, rectangular, etc.

\section{Spot the adjective}

The teacher reads out a story. The students raise their hands every time they hear an adjective. Alternatively, the teacher can distribute copies of a simple story. The students can spot the adjectives and color them.

\section{Feel and describe}

The teacher puts some objects in a bag. She asks a student to come up and feel the object. He/she has to describe the object without looking at it. For example, if it's a wooden scale, the description could be, "It is long and flat and hard". The others try to guess what the object is.

\section{Go fish}

Several words, some nouns, some adjectives, some verbs can be written on cards, which can be scattered on the ground. The children should be able to read the words clearly. A fishing rod can be made with a magnet attached to a stick. Each card will have a metallic gem clip attached. The children can be asked to go fishing. They will identify the cards with the adjectives written on them and pick them up with the fishing rod.

\section{Make a chain}

Ask a student to randomly think of any adjective. The next person has to think of an adjective with the last letter of the previous adjective. Keep going till everyone gets a chance.

\section{Describing people}

The students are asked to collect pictures of different kinds of people. They are then asked to describe the people. They can be further guided to describe the structure, the face, the eyes, the nose, etc. in detail. For example, "He has a sharp nose", she has slanted eyes, he has a cheerful face etc.

\section{Describing your friend}

Once the students know how to describe a person, this activity can be taken up. Each student is asked to choose a friend that he/she wants to describe. They can be guided to describe the physical characteristics (looks) first, for example, "She is tall", "She is thin", etc. and then the nature of the person, for example, "She is kind", "She is friendly" etc.

\section{Introduce yourself}

Ask the students to introduce themselves. They say their names and use adjective to describe themselves. For example, "I am cheerful Beena" or "I am curious Rohan". To the students of higher classes, alliteration can be introduced. The students could be encouraged to use adjectives with first 
letters of their names. For example, "I am simple Shweta", both starting with the letter "S".

\section{RESEARCH METHODOLOGY}

This research was conducted this study at SMA Swasta Persiapan Stabat. The school is on JalanI.B Tambeleng Pantai Gemi Kecamatan Stabat Kabupaten Langkat. The population of this study is the tenth grade students at SMA Swasta Persiapan Stabat in academic year 2017/2018. There are six classes at this grade with the total number of 244 students. The writer took some of the population as the sample of the study. Considering to what Arikunto says that "if the subjects are large, sample can be $15 \%$ or $20-25 \%$ or more depending on the researcher's ability due to her time and fund". For efficiency and practicality, the writer took one class as the sample randomly by applying lottery technique. The writer wrote the name of each class on a small piece of paper and put these six pieces of paper on a glass. By closing the eyes, the writer took out one piece of paper. Whichever the class written on the paper, it became the sample of the study. After doing this step, the small paper which was taken out was written as class X IPA-2. So, class X IPA-2 with 43 students became the sample of the study. The sample was around $18 \%$ of the population of the tenth year students of SMA Swasta Persiapan Stabat.

To get the data of adjective mastery, the writer gave test of adjective by providing 25 numbers of questions in the form of multiple choices. After the students finished the test and collected the answer sheet, the writer checked the answer sheet and gave their scores. Each correct answer was scored 4. So, if a student got 20 correct answers, so his/her score was 80 .

To get the data of the students' writing ability in descriptive text, a composition test in the form of writing test was given to the students. In scoring the student' ability in writing, the writer applied" J.B Heaton criterion":

1. Content

In scoring the contents it depends on the students' ability to write their ideas and information in the form of logical order.

2. Organization

The organization refers to the students' ability to write ideas and information in good logical order. The topic and supporting sentences are clearly stated.

3. Vocabulary

Vocabulary in writing here refers to the collection of words used by the writer which should appropriate and suitable to support the ideas. In other words, the writer should select and choose best words for developing his ideas.

4. Language use

Language use refers to someone's capability in writing down the sentences simple, complex, or compound sentences correctly and logically. It also refers to the ability to use agreement sentences and some other word such as nouns, adjectives and time signals.

5. Mechanics

Mechanics refers to the accurate use of spelling, letter and punctuations in writing. The followings are the description of the scoring system for testing writing ability. 
Table 1. The Description of Scoring Writing Test

\begin{tabular}{|c|c|c|c|}
\hline No & Criteria & Description & Score \\
\hline 1. & Content & $\begin{array}{l}\text { Excellent to Very Good: Knowledge able } \\
\text { substantive through development of topic } \\
\text { sentences - relevant to the assigned topic. } \\
\text { Good to Average: for students with some } \\
\text { knowledge able to population adequate of range } \\
\text { limited development-mostly relevant to topic } \\
\text { sentences but look details. } \\
\text { Fair to Poor: for students with limited } \\
\text { knowledge of population little substance in } \\
\text { adequate development of population. } \\
\text { Very Poor: Where a student non substantive not } \\
\text { pertinent or not enough to evaluate. }\end{array}$ & 2 \\
\hline 2. & Organization & $\begin{array}{l}\text { Excellent to Very Good: Where students are } \\
\text { ready to provide fluent expression ideas clearly } \\
\text { stated- well organized - logical sequencing } \\
\text { cohesive. } \\
\text { Good to Fair : Students provide clear ideas, } \\
\text { fairly well organized - logical sequencing and } \\
\text { development. } \\
\text { Fair to Poor : Non fluent ideas confused or } \\
\text { disconnected lack logical sequencing and } \\
\text { development. } \\
\text { Very Poor : Does not communicate, no } \\
\text { organization or not enough to evaluate. }\end{array}$ & 2 \\
\hline 3. & Vocabulary & $\begin{array}{l}\text { Excellent to Very Good: Students with } \\
\text { sophisticated range, effective word and using } \\
\text { word form mastery, appropriate register. } \\
\text { Good to Fair: Adequate range, occasional } \\
\text { errors meaning not observed. } \\
\text { Fair to Poor: Limited range, frequent errors of } \\
\text { words, idioms, form of choice usage, but } \\
\text { meaning confused or obscured. } \\
\text { Very Poor: Lack of essential translation, little } \\
\text { knowledge of English vocabulary, idioms, word } \\
\text { form, or not enough to evaluate. }\end{array}$ & $\begin{array}{l}3 \\
2\end{array}$ \\
\hline 4. & Language Use & $\begin{array}{l}\text { Excellent to Very Good: Effective complex } \\
\text { construction, few errors of agreement, tense } \\
\text { number, word order/function words, articles, } \\
\text { pronouns, prepositions. } \\
\text { Good to Fair: Effective but simple } \\
\text { constructions several errors of agreement; tense } \\
\text { number, word order/ function word, articles, } \\
\text { pronouns, preposition. }\end{array}$ & 4 \\
\hline
\end{tabular}




\begin{tabular}{|l|l|l|l|}
\hline & \multicolumn{1}{|c|}{$\begin{array}{l}\text { Fair to Poor: Major problem in simple complex } \\
\text { constructions, frequent errors of negations, } \\
\text { agreement, number, etc. } \\
\text { Very Poor: Virtually no mastery of sentences } \\
\text { constructions, not enough to evaluate. }\end{array}$} & 2 \\
\hline 5. & Mechanics & $\begin{array}{l}\text { Excellent to Very Good: Demonstration } \\
\text { mastery of conversations, few errors in spelling, } \\
\text { punctuation, capitalization in writing sentences. } \\
\text { Good to Fair: Occasional errors on spelling, } \\
\text { punctuation, and capitalization in writing } \\
\text { sentences but meaning not obscured. } \\
\text { Fair to Poor: common errors on spelling, } \\
\text { punctuation, capitalization in writing sentences, } \\
\text { meaning is obscured. } \\
\text { Very Poor: No mastery of conversations } \\
\text { dominated by errors of spelling, punctuation, } \\
\text { capitalization in writing sentences, hand writing } \\
\text { illegible, not enough to evaluate. }\end{array}$ & 21 \\
\hline
\end{tabular}

After the data were collected from the test, then the writer analyzed them. To analyze the data, the writer applied Pearson Product Moment formula," as follow:

$$
\mathrm{r}_{\mathrm{xy}}=\frac{\left(N \cdot\left(\sum \mathrm{XY}\right)\right)-\left(\left(\sum \mathrm{X}\right)\left(\sum \mathrm{Y}\right)\right)}{\sqrt{\left.\left.\left(\left(N \cdot \sum \mathrm{X}^{2}\right)-\left(\sum \mathrm{X}\right)^{2}\right)\right)-\left(\left(N \cdot \Sigma \mathrm{Y}^{2}\right)\left(\sum \mathrm{Y}\right)^{2}\right)\right)}}
$$

In which:

$\mathrm{N}=$ the number of samples

$\sum X=$ sum of $\mathrm{X}$ scores of adjective mastery

$\sum Y=$ sum of $Y$ scores of writing descriptive text

$\sum X^{2}=$ sum of the squared $\mathrm{X}$ scores of adjective mastery

$$
\sum Y^{2}=\text { sum of the squared } \mathrm{Y} \text { scores of writing }
$$

descriptive text

$\sum X Y=$ sum of the products of paired $\mathrm{X}$ and $\mathrm{Y}$ score

This study is to find out the correlation between students' adjective mastery and their ability in writing descriptive text. Therefore, the data got from the test were important to be analyzed. In order to know how much the correlation coefficient between them, the two variables were calculated by using Pearson Product Moment formula as follows:

$$
\mathrm{r}_{\mathrm{xy}}=\frac{\left(N \cdot\left(\sum \mathrm{XY}\right)\right)-\left(\left(\sum \mathrm{X}\right)\left(\sum \mathrm{Y}\right)\right)}{\sqrt{\left.\left.\left(\left(N \cdot \Sigma \mathrm{X}^{2}\right)-(\Sigma \mathrm{X})^{2}\right)\right)\left(\left(\left(N \cdot \Sigma \mathrm{Y}^{2}\right)\right)-(\Sigma \mathrm{Y})^{2}\right)\right)}}
$$

From the previous data, the correlation coefficient of both variables can be calculated as in the following: 


$$
\begin{aligned}
& r_{x y}=\frac{(43(199820))-((2856)(2990))}{\sqrt{\left.\left.\left((43 \times 191232)-(2856)^{2}\right)\right)\left(((43 \times 209500))-(2990)^{2}\right)\right)}} \\
& r_{x y}=\frac{(8592260)-(8539440)}{\sqrt{((8222976)-(8156736))((9008500))-(8940100))}} \\
& r_{x y}=\frac{52820}{\sqrt{(66240 \times 68400)}} \\
& r_{x y}=\frac{52820}{\sqrt{4530816000}} \\
& r_{x y}=\frac{52820}{67311} \\
& r_{x y}=0.78
\end{aligned}
$$

The data analysis above shows that the coefficient of correlation between the two variables was 0.78 . Then, to know the degree of the correlation, it was compared with Jackson's table of degree of correlation.

The degree of correlation could be represented as the following table.

\section{Table 2. The Degree of Correlation Coefficient}

\begin{tabular}{|l|l|}
\hline Correlation coefficient & Degree of correlation \\
\hline $0.70-1,00$ & Strong \\
\hline $0.30-0.69$ & Moderate \\
\hline $0.00-0.29$ & None to weak \\
\hline
\end{tabular}

If we compare the coefficient correlation found in this study with table 4.4 above, we could see that the coefficient correlation 0,78 lies between 0.70 and 1.0 . This means that the correlation between the students' adjective mastery and their writing descriptive text ability is strong.

From the calculation of the value of $r_{x y}$ is 0.78 , the critical value of the correlation with $\mathrm{df}=43-2=41$ is 0.257 for the 0.05 level of significance, and 0,358 for the 0,01 level of significance. So the $r$ value is higher than the critical value for both 0,05 and 0,01 level of significance $(0,78>0,257$ or $0,78>0,358)$. It means that the hypothesis of this study is accepted.

The finding showed that there is a significant correlation between the adjective mastery and writing descriptive text ability of the 2017/2018tenth year students of SMA Swasta Persiapan Stabat.

\section{CONCLUSION}

Having analyzed the data and found the result, the writer concludes that there is a significant correlation between the adjective mastery and writing descriptive text ability of the 2017/2018tenth year students of SMA Swasta Persiapan Stabat. This is proved from the analysis that the coefficient correlation between the students' adjective mastery and writing descriptive text ability is 0.78 . Compared with the degree of correlation, it is categorized as a strong and significant correlation. Therefore, the hypothesis of the study is accepted.

\section{REFERENCES}


Arikunto, Suharsimi. ProsedurPenelitian: SuatuPendekatanPraktik. Jakarta : Rineka Cipta. 2006

Boardman, Cynthia A. Writing to communicate. New York: Pearson Education. 2008

Brinton, Laurel J. The Structure of Modern English. Amsterdam: John Benjamins Publishing Company. 2000

Brown, H. Douglas. Teaching by Principles. An Interactive Approach to Language Pedagogy, (San Francisco State University. 2000

Byrne. W. Techniques for Classroom Interaction. Essex: Longman. 2009

Dykes, Barbara. Grammar for Everyone. Victoria: ACER Press. 2007

Ehrlich, Eugene. English Grammar. New York: McGraw Hill. 1991

Harmer Jeremy. How to Teach Writing. Essex: Pearson Longman. 2004

Heaton, J.B. Writing English Language Tests. New York: Longman. 1989

Hudson, R. English Word Grammar. Oxford: Blackwell. 2000

Jain, T.R and Aggawal. Statistics. New Delhi: V.K Enterprises. 2011

Lomax, Richard G. An Introduction to Statistical Concepts. New Jersey: Lawrence Erlbaum Associates, Inc. 2007

Pharr, Donald and Santi V. Buscemi. Writing Today. New York: McGraw-Hill. 2005

Priyana, Joko. Interlanguage. Jakarta: Pusat Perbukuan. 2008

Richards, J.C. and Renandya, W.A. Methodology in Language Teaching: An Anthology of Current Practice. Cambridge: Cambridge University Press. 2002

Sargeant, Howard. Basic English Grammar. California: Saddleback Education Publishing. 2007

Tonfoni, Graziella. Writing as a Visual Art. Maryland: Scarecrow Press Inc. 2000 http://english-text.blogspot.com/search/label/Descriptive\%20Text, accessed on 21 May 2017

http://www.omniglot.com/writing/definition.htm, accessed on 23 May 2017

http://www.teachersofindia.org/en/activity/fun-adjectives, accessed on 12 June 2017 